\title{
Hepatic Iron In Type II Diabetes
}

\author{
Mahmoud M. Bazid*, Abd Al-Monem H. Barrak*, Hani Abu Zeid*, Mohamad \\ Abd El-Aziz Fahmy**, Abd Ellah Abu Srie** \\ Internal Medicine*, Biochemistry** Departments, Al-Azhar \\ Faculty of Medicine.
}

\begin{abstract}
The present work was carried on forty patients with type II diabetes of variable durations of the disease. They were selected from Internal Medicine Department, Sayed, Galal Al-Azhar University Hospital. They were 18 males and 22 females and their age ranged from 41 to 65 years. Twenty normal volunteer subjects were selected as a control group ( 9 males and 11 females and their age ranged from 45 to 65 years).

A full clinical evaluation was done. Labaratory investigations were also performed that included measurement of plasma fasting and postprandial glucose, urea, creatinine, alanine amino transferase (ALT), aspartate aminotransferase (AST), bilirubin (total and direct), ANA, iron, ferritin, insulin ( fasting and postgrandial as well as hepatitis markers (HbsAg and $\mathrm{HCVAb}$ ). Liver biopsy was taken for assessment of hepatic tissue iron concentration and histologic assessment. The results revealed that there is a significant difference between cases with type II diabetes and normal control as regarding insulin level $(\mathrm{P}<0.05)$. Also a significant relation was noted between high fasting insulin level and increased body mass index (BMI) especially above 30 . Also cases with type II diabetes with steatosis or steatohepatitis had significantly higher fasting insulin level than cases without $(\mathrm{P}<0.05)$. Our results showed that there is a significant high hepatic iron concentration, serum ferritin and serum fasting insulin in patients compared with control group $(\mathrm{P}<0.05)$. Also there is a significant increase in HIC and serum ferritin among cases with longer duration of diabetes, together with significant increase in steatosis and steatohepatitis among those cases. In addition, elevated serum ferritin in female cases were of high significance $(\mathrm{P}<0.01)$ in comparison to significant elevation in male cases $[\mathrm{P}<0.05]$, this may be explained by the fact that females have higher BMI than males.
\end{abstract}

\section{Introduction}

Type II diabetes is one of the metabolic conditions associated with high rate of insulin resistance and is frequently associated with increased serum ferritin level (Kaye et al., 1993). In addition Mendler et al., 1999 described the association of hepatic iron overload, steatosis and presence of one or more components of insulin resistance syndrome Bonara et al., 1998 suggested the role of insulin resistance in the development of hepatic iron. Iron overload, steatosis and increased serum ferritin level. Hepatic steatosis is known to be associated with insulin resistance. Iron accumulation may also appear to be associated with insulin resistance (Fernandez et al., 1998). The mechanism whereby insulin resistance would induce alterations in iron metabolism remains to be elucidated (Vigano et al., 2000). One of the most interesting questions now is the nature of the relationship between hepatic steatosis and iron overload (Macdonald et al., 1999). The aim of this work was to study the relationship between hepatic iron and type II diabetes mellitus.

\section{Patients And Methods}

The present work was conducted on forty patients with type II diabetes of variable durations of the disease selected from internal medicine department at Sayed Galal - Al-Azhar University Hospital (18 


\section{Hepatic Iron In Type II Diabetes}

males and 22 females, age ranged from 41 to 65 years) and twenty normal subjects as a control group (9 male and 11 females, with age ranged from 45 to 65 years ).

\section{All are subjected to: -}

(1) Full clinical history.

(2) Full clinical evaluation: to assess the general condition and to exclude other diseases e.g. chronic liver diseases, anemias, malignancy.

(3) Laboratory investigations: -

- Fasting \& P.P plasma glucose.

- Renal function tests: serum urea and creatinine.
○ Liver function tests: - serum alanine aminotransferase (ALT). - serum aspartate aminotransferase (AST).

- serum bilirubin (total and direct).

4- Hepatitis markers: HbsAg, HCV-Ab,

5. ANA.

6- Serum iron level.

7- Serum ferritin level.

8-Serum insulin level: fasting and postprandial.

9-Liver biopsy:

-a) Histopathologic assessment.

-b)Assessment of hepatic iron concentration[HIC]

\section{Results}

Table (1): Comparison between diabetics and control group for serum iron, hepatic iron concentration serum ferritin and serum fasting insulin.

\begin{tabular}{|l|l|l|l|l|l|}
\hline Lab. Investig. & Range & Diabetic & Control & $\mathrm{T}$ & $\mathrm{P}$ \\
\hline \multirow{2}{*}{$\begin{array}{l}\text { Serum } \\
\text { Iron }\end{array}$} & Range & $48.9-163$ & $51-86$ & 1.47 & $>0.05$ \\
\hline & $\mathrm{X} \pm$ SD & $83.02 \pm 35.72$ & $60.75 \pm 12.81$ & & \\
\hline \multirow{2}{*}{$\begin{array}{l}\text { Hepatic } \\
\text { Iron }\end{array}$} & Range & $622-1801$ & $432-844$ & 2.24 & $<0.05$ \\
\cline { 2 - 7 } & $\mathrm{X} \pm$ SD & $1012 \pm 392.58$ & $636 \pm 164.11$ & & \\
\hline $\begin{array}{l}\text { Serum } \\
\text { Ferritin }\end{array}$ & Range & $30-720$ & $30-190$ & 1.95 & $<0.05$ \\
\hline & $\mathrm{X} \pm$ SD & $281.86 \pm 288.79$ & $93.83 \pm 72.09$ & & \\
\hline $\begin{array}{l}\text { Fasting } \\
\text { Insulin }\end{array}$ & Range & $3-122$ & $5-30$ & 2.19 & $<0.05$ \\
\hline & $\mathrm{X} \pm$ SD & $49 \pm 40.32$ & $20.67 \pm 12.23$ & & \\
\hline & & & & & \\
\hline
\end{tabular}

- There was no statistical significant difference between diabetics and control groups for serum iron.

- Diabetics showed a significant high levels of hepatic iron, ferriton and fasting serum insulin in comparison to control group.

\section{Measurement Units:}

- Serum insulin : $\mathrm{mlU} / \mathrm{ml}$.

- Serum iron : mcg./dL.

- Serum ferritin: $\mathrm{ng} / \mathrm{ml}$.

- HIC: $\mathrm{mcg} / \mathrm{g}$. dry weight. 
Table (2): Comparison between diabetics and control group in studied variables: -

\begin{tabular}{|c|c|c|c|c|c|c|}
\hline Variables & \multicolumn{2}{|c|}{ Diabetics } & \multicolumn{2}{|c|}{ Control } & \multirow[t]{2}{*}{$\mathrm{X}^{2}$} & \multirow[t]{2}{*}{$\mathrm{P}$} \\
\hline \multirow[b]{2}{*}{ Biochemical marker } & No & $\%$ & No & $\%$ & & \\
\hline & \multirow[b]{2}{*}{4} & \multirow[b]{2}{*}{10} & \multirow[b]{2}{*}{0} & \multirow[b]{2}{*}{0} & \multirow{3}{*}{2.14} & \multirow{3}{*}{$>0.05$} \\
\hline Serum iron $>160$ & & & & & & \\
\hline$\leq 160$ & 36 & 90 & 20 & 100 & & \\
\hline $\begin{array}{l}\text { Serum ferritin } \\
\text { In } M>501\end{array}$ & 9 & 50 & 0 & 0 & & \\
\hline$\leq 501$ & 9 & 50 & 9 & 100 & 7.94 & $<0.001$ \\
\hline $\begin{array}{l}\text { In F > 223.5 } \\
\leq 223.5\end{array}$ & $\begin{array}{l}6 \\
16\end{array}$ & $\begin{array}{l}27 \\
73\end{array}$ & $\begin{array}{l}0 \\
11\end{array}$ & $\begin{array}{l}0 \\
100\end{array}$ & 3.19 & $>0.05$ \\
\hline \multicolumn{7}{|l|}{$\begin{array}{l}\text { Histopathology } \\
\text { Steatosis }\end{array}$} \\
\hline -ve & 17 & 42.5 & 15 & 75 & & \\
\hline$+\mathrm{ve}$ & 23 & 57.5 & 15 & 25 & 15.66 & $<0.05$ \\
\hline $\begin{array}{l}\text { Steatohepatitis } \\
\text { - ve } \\
+ \text { ve }\end{array}$ & $\begin{array}{l}31 \\
9\end{array}$ & $\begin{array}{l}77.6 \\
22.4\end{array}$ & $\begin{array}{l}20 \\
0\end{array}$ & $\begin{array}{l}100 \\
0\end{array}$ & 32.3 & $<0.001$ \\
\hline $\begin{array}{l}\text { Fasting insulin level } \\
>22\end{array}$ & 23 & 57.5 & 6 & 30 & & \\
\hline$\leq 22$ & 17 & 42.5 & 14 & 70 & 4.04 & $<0.05$ \\
\hline
\end{tabular}

- There was no significant difference between diabetics \& control group in the number of individual with abnormal serum iron level.

- 50\% of male diabetics had elevated serum ferritin in contrast to $0 \%$ in control group with high significant difference.

- The number of diabetic with steatosis and steatohepatitis was significantly higher in patients than the control group.

- The number of diabetics with elevated fasting insulin was significantly higher than the control group.

N.B.: $\mathrm{M}=$ Male, $\quad \mathrm{F}=$ Female.

Table (3): Correlation between duration of the disease and hepatic iron concentration and serum ferritin level.

\begin{tabular}{|l|l|l|l|l|}
\hline Variables & $\begin{array}{l}\text { Cases with duration } \\
>5 \text { years }\end{array}$ & $\begin{array}{l}\text { Cases with duration } \\
\leq 5 \text { years }\end{array}$ & T & P \\
\hline $\begin{array}{l}\text { Hepatic iron } \\
\text { Mean } \pm \text { SD }\end{array}$ & 100g. $63 \pm 463.66$ & $785.58 \pm 311.09$ & 2.11 & $<0.05$ \\
\hline $\begin{array}{l}\text { Serum ferritin } \\
\text { Mean } \pm \text { SD }\end{array}$ & $304.75 \pm 210.66$ & $172.58 \pm 113.05$ & 2.01 & $<0.05$ \\
\hline
\end{tabular}

There was a significant increase in hepatic iron concentration and serum ferritin level among diabetics with longer duration of the disease.

Table (4): Relation between duration of the disease and steatosis or steatohepatitis.

\begin{tabular}{|l|l|l|l|l|}
\hline Variables & $\begin{array}{l}\text { Cases with steatosis } \\
\text { or steatohepatitis }\end{array}$ & Free cases & $\mathrm{T}$ & $\mathrm{P}$ \\
\hline $\begin{array}{l}\text { Mean } \pm \text { SD of duration } \\
\text { (years) }\end{array}$ & $9.17 \pm 5.51$ & $1.5 \pm 0.17$ & 2.56 & $<0.01$ \\
\hline
\end{tabular}

Cases with steatosis or steatohepatitis had longer duration of the disease than free cases with highly significant difference. 


\section{Hepatic Iron In Type II Diabetes}

Table (5): Correlation between fasting insulin level and body mass index (BMI)

\begin{tabular}{|l|l|l|}
\hline Fasting insulin & BMI \\
\hline \multirow{3}{*}{$>22$} & $>30$ & $\leq 30$ \\
\cline { 2 - 3 }$\leq 22$ & 20 & 3 \\
\cline { 2 - 3 } $\mathrm{X}^{2}$ & 3 & 14 \\
\hline $\mathrm{P}$ & 5.83 & \\
\hline
\end{tabular}

- There was significant correlation between fasting insulin level and increased BMI.

Table (6): Correlation between fasting insulin level and HIC (hepatic iron concentration) and serum ferritin level.

\begin{tabular}{|l|l|l|}
\hline Correlation & Coefficient correlation & Significant \\
\hline Fasting insulin and HIC & +0.35 & $<0.05$ \\
\hline Fasting insulin \& serum ferritin & +0.33 & $<0.05$ \\
\hline
\end{tabular}

There was significant positive linear correlation between fasting insulin level and both HIC and serum ferritin.

Table (7): Relation between fasting insulin level and steatosis and steatohepatitis

\begin{tabular}{|l|l|l|l|l|}
\hline Variable & $\begin{array}{l}\text { Cases with steatosis or } \\
\text { steatohepatitis }\end{array}$ & Free cases & T & P \\
\hline $\begin{array}{l}\text { Mean } \pm \text { SD of fasting } \\
\text { insulin level }\end{array}$ & $53.17 \pm 43.18$ & $23 \pm 22.16$ & 1.95 & $<0.05$ \\
\hline
\end{tabular}

Cases with steatosis or steatohepatitis had significant higher fasting insulin levels than cases without.

\section{Discussion}

Patients with type II diabetes mellitus are known to have insulin resistance which is associated with many defects as iron overload, steatosis and obesity (Raven, 1998). Increased HIC and serum ferritin are clear indicators of iron overload while increased serum fasting insulin is a known evidence of insulin resistance (Haffner et al., 1992). In the present study, the results showed that there is a significant difference $(\mathrm{P}<0.05)$ between cases with type II diabetes and control group as regard fasting insulin level (Table 2). This is supported by Bonora et al.,1998 who stated that the prevalence of insulin resistance in type II D.M is $(83.9 \%)$. Also, a significant correlation was noted between high fasting insulin level and increased BMI (above 30 indicating obesity), denoting an association with insulin resistance (Knobler et al., 1999). Also, in the present work, $23 \%$ of patients with type II diabetes had steatohepatitis and $57 \%$ of them had steatosis (of all with steatosis or steatohepatitis, $85 \%$ were obese with BMI > 30), this is supported by Batman and Scheuer, 1985 who stated that steatohepatitis was found in $24.2 \%$ of diabetic patients, study of Sanyal et al., 2001 also showed the association of non alcoholic steatohepatitis [NASH] with insulin resistance and mitochondrial abnormalities in the present work, results showed also that cases with type II D.M. with steatosis or steatohepatitis had significant higher fasting insulin level than cases without steatosis or steatohepatitis $(\mathrm{P}<0.05)$, (Table7). This observation is supported by Marchesini et al., 1999, who stated also, that non-cirrhotic patients with non-alcoholic fatty liver disease have significantly higher fasting insulin levels as well as greater index of beta cell dysfunction and a greater index of insulin resistance.

In the present work, results showed that there is significant difference between diabetics and controls regarding HIC, serum ferritin and fasting insulin; all are elevated in diabetics with $\mathrm{P}<0.05$. Also, there is a significant increase in HIC and serum ferritin among diabetics with longer duration of the disease, together with a significant increase in steatosis and 
steatohepatitis among those diabetics. These results supported by Vigano et al., 2000 who demonstrated that elevated serum ferritin concentration and hepatic iron concentration (HIC) and steatosis in 10 patients with poorly controlled type II diabetes .Of them $80 \%$ had steatosis with mild necroinflammatory activity. After one year of glycemic control, steatosis decreased (in 30\% of patients), serum ferritin level decreased in all patients, while HIC decrease in 5 patients of 6 who accept a second liver biopsy.

In this study, it is also noted that, the longer the duration of the disease, the more increase in fasting insulin level (the sign of IRS). In addition, elevated serum ferritin in diabetics females were of high significance $(p<0.01)$ in comparison to diabetic males $(\mathrm{p}<0.05)$. This may be explained by the fact that females have higher BMI (which was found to has higher fasting insulin levels with $p<0.05$ ) than males.

The mechanism whereby insulin resistance would induce alteration in iron metabolism remains to be elucidated (Vigano et al., 2000). One of the most interesting questions now is the nature of the relationship between hepatic steatosis and iron overload. There are several possibilities; iron accumulation could result in steatosis, hepatic steatosis could lead to iron accumulation. Both iron overload and steatosis may be distinct consequences of another factor (propably insulin resistance), and finally, hepatic iron overload and steatosis may be unrelated but occurring together coincidentally (MacDonald et al., 1999). Hepatic steatosis is known to be associated with insulin resistance, while iron accumulation may also appear to be associated with insulin resistance (Fernandez et al., 1998). The most likely explanation seems to be that the same factors that lead to hepatic steatosis also resulted in iron accumulation (MacDonald et al., 1999).

\section{Conclusion}

This study showed that there are significant correlations between degree of insulin resistance (increased fasting insu- lin), iron overload (increased HIC and seru$\mathrm{m}$ ferritin), and presence of hepatic steatosis and steatohepatitis. All are correlated with increased BMI. So, the insulin resistance syndrome may be the thread that links hepatic iron overload and steatosis.

\section{References}

1- Batman PA and Scheuer PJ: Diabetic hepatitis preceding the onset of glucose intolerance. Histopathology 1985;9:237-243

2- Bonora, E.; Kiechl, S.; Welliet, J. et al.,: Prevalence of insulin resistance in metabolic disorders. Diabetes, 1998; 47: 1643-1649

3- Fernandez, R.J.; Ricart, E.W.; Arroyo, E. et al: Serum ferritin as a component of the insulin resistance syndrome. Diabetic care 1998; 21:62-68

4- Haffner, S.M.; Valdez, R.; Hazudd, H. et al.: Prospective analysis of the insulin resistance syndrome (syndrome $\mathrm{X}$ ). Diabetes, 1992; 41: 715-722

5- Kaye, T.B.; Guay A.T. and Simonson, D.C. : Non-insulin dependent diabetes mellitus and elevated serum ferritin levels. J diabetic complications, 1993; 7: 246-249

6- Knobler, H.; Schattner, A.; Zhornick, T, et al.: Fatty liver and additional and treatable feature of the insulin resistance syndrome. Q J M, 1991 92: 73-79

7- MacDonald, G.A.; and Powell, L.W. : More clues on the relationship between hepatic iron and steatosis: an association with insulin resistance Gastroenterology, 1999;117:1241-1244.

8- Marchesini, G.; Brizi, M.; Morsilli, A.et al.: Association of non-alcoholic fatty liver disease with insulin resistance. Am . J. Med. 1999; 107: 450-455

9- Mendler, M.H.; Turlin, B.; Moirand, R. et al. : Insulin resistance associated hepatic iron overload. Gastroenterology, 1999; 117: 1115-1163

10- Raven, G.M. : Role of insulin resistance in human disease. Diabetes, 1988; 37: 1595-1607

11- Sanyal, A. J.; Campbell, C.; Mershahi, F. et al. : NASH associated with insulin resistance and mitochondrial abnormalities. Gastroenterology, 2001; 120: 1183-1192

12- Vigano, M.; Anna, V.; Paola, T. et al. : Insulin resistance influences iron metabolism and hepatic steatosis in type 2 diabetes. Gastroenterology, 2000; 118: 986989. 


\title{
نسبة الحديد في الكبد في النوع الثاني من مرضى البوال السكري
}

محمود موسى بازيد * ـ عبد المنعم براكث ـ هاني أبو زيد * ـ محمد عبد

\author{
العزيز

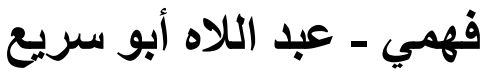

قسم الباطنة العامة** ـ الكيمياء الحيوية الطبية ـ طب بنين الازهر

مرض البوال السكري يؤثر على الأيض من وجوه عديدة، ومن أحثث ما تم

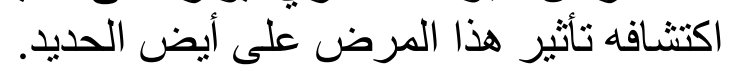
أيض الحديد ينم في الجسم في أعضاء كثبرة بصورة متكاملة ولكن أبرز وأهم هذه الأعضاء هو الكبد.

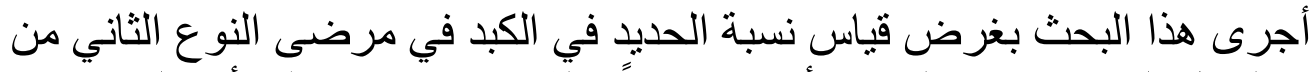

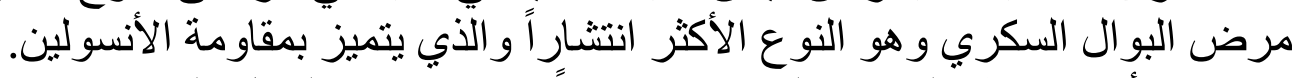

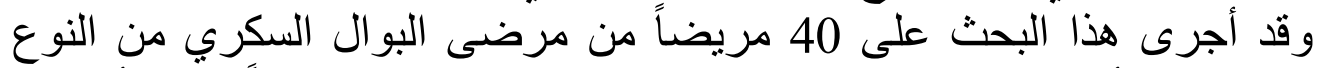

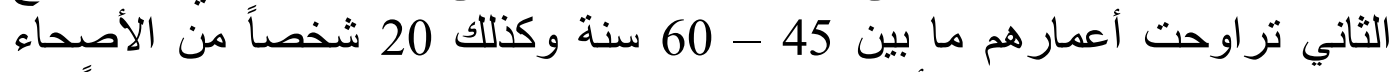

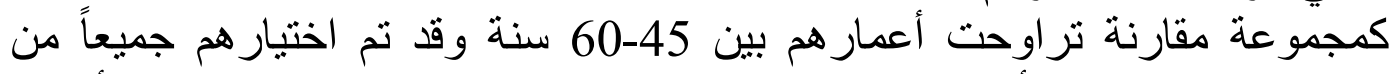
المترددين على قسم الأمر اض الباطنة بمستشفى باب الثنعرية الجامعي، وقد تم أجراء

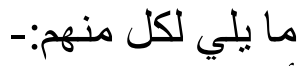
أخذ التناريخ المرضي وأجراء الفحص الإكلينيكى. قياس السكر بالدم صنائماً وبعد الإفطار.

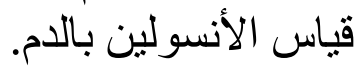
ق قياس نسبة الحديد ونسبة الفرتين [ البروتين الماسك للحديد ] بالدم. أنزيمات الكبد والصفر اء. ألاء. ، ل الائل الفيروسات الكبدية و الأجسام المضادة للحامض النووي.

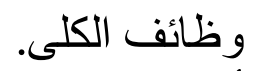

أخذ عينة من الكبد ثم فحصها نسيجياً (هستولوجياً) وقياس نسبة الحديد بها وقد

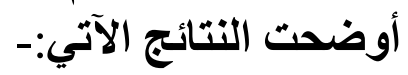
ارتفاع نسبة الحديد بكبد مرضى البو ال السكري عن أقرانهم الأصحاء ارتفاعاً ذو دلالة أرتفاع نسبة الفرتين بالدم بمرضى البوال السكري عن أقرانهم الأصحاء ارتفاعاً ذو دلالة ورجود تثحم بالكبد والتهاب كبدي تثتحمي بنسبة كبيرة بمرضى البوال السكري تفوق أقر انهم الأصحاء تفوقاً ذو دلالة إنصائية. وجود علاقة طردية بين ارتفاع نسبة الحديد بالكبد و الفرتين بالدم بمرضى البوال السكري وارتفاع مقاومة الأنسولين بنفس المرضى. 
و وجود علاقة بين ارتفاع الحديد بالكبد وحدوث تثحم أو التهاب كبدي تشحمي بمرضى البو ال السكري.

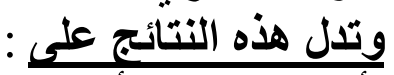

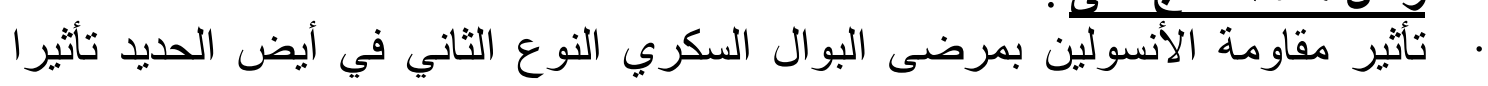
يؤدي إلى زيادة نسبة الحديد بالكبد. · احتمالية وجود علادة علاقة بين مقاومة الأنسولين وزيادة نسبة الحديد بالكبد بحدوث التشحم بالكبد و الالتهاب الكبدي التشحمي. 